\title{
Seeking Identities Across the Worlds---A Critical Analysis of Ang Lee's Film The Wedding Banquet
}

\author{
Jiefei $\mathrm{Yu}^{1}$ \\ ${ }^{1}$ International College, Guangdong University of Foreign Studies, Guangzhou, China \\ Correspondence: Jiefei Yu, International College, Guangdong University of Foreign Studies, Guangzhou, China. \\ E-mail:309327657@qq.com
}

Received: June 6, 2019

Accepted: August 20, 2019

Online Published: August 31, 2019

doi:10.5539/ach.v11n2p91

URL: https://doi.org/10.5539/ach.v11n2p91

\begin{abstract}
Up till the present, most researches on Ang Lee's films focused on cultural difference and cultural clash in the area of cultural studies. The identity problems facing by the Asian diasporas are neglected by past researchers. Based on the exploration of cultural identity from the perspective of diaspora in cross-cultural world, this paper picks up the Chinese English film The Wedding Banquet as an exemplification to interpret cultural identity politics of the immigrants in America. In the film The Wedding Banquet, the protagonists' identities are fragmented as the coming of the joyous parents comes from Taiwan for the wedding. This exploration of identity can help us to understand the exilic essence of the immigrants' identity. For the immigrants, identity is always floating and travelling, without a final destination, except some temporary location. The happy ending of the film could be viewed as the "hybridization" of cultural recognition and as the ultimate solution to the identity problem and the Chinese-American cultural confrontation.
\end{abstract}

Keywords: Migrant, Wedding Banquet, Homosexual, Cultural Identities

\section{Introduction}

\subsection{Situating Ang Lee's Film the Wedding Banquet}

Ang Lee was born in Taiwan while educated in America.On the one hand, being influenced by his family, he was rooted with the traditional Chinese culture like Taoism and Confucianism. On the other hand, more than twenty years' life in American offered him the opportunity to receive Western education. Standing at the intersection between different cultures, he goes deep into the Chinese traditional culture as well as manages to justify it through a different lens with the penetration of Western culture. The reason why I choose The Wedding Banquet (1993) directed by Ang Lee to study is because of its primary plot---interracial romance. The struggle for love and individuality is closely connected with the protagonists' complicated identities by way of negotiation between personal, familial, communal, and social concerns, which is used to suggest the intersection of gender, class, ethnicity, and nationalism in Asian Diasporas' pursuit of their reconstructed identities.

The film The Wedding Banquet has been honored at film festivals and hailed around the world. The prizes won include the nomination for the best foreign film at the 1994 Academy Awards, the Golden Space Needle of the Seattle International Film Festival and the Golden Bear by the Berlin International Film Festival. It tells a story about a young Chinese Immigrant-Wei-Tung's life in America. Simon and Wei-Tung are a gay couple living together in Manhattan. To still the doubts of Wei-Tung's parents, Simon suggests a marriage of convenience between Wei-Tung and Wei-wei, an immigrant in urgent need of a green card. Complications arise when the joyous parents arrive for the wedding and a huge cross-cultural banquet is arranged to celebrate. However, being trickled by the guests in the wedding, Wei-wei seduces the drunken Wei-Tung and becomes pregnant. Simon is extremely sad when he finds it out, and his relationship with Wei-Tung begins to deteriorate. After several chaotic scenes of generational and cultural conflicts in the Gao's family, the film ends with a reconciliation: Wei-wei agrees to give birth to Wei-Tung's baby while Mr. and Mrs. Gao return to Taiwan with an acceptance of the gay couple's partnership.

\section{Literature Review}

Up till the present, there are many researches on Ang Lee's films. Most of the studies paid attention to its distinctive artistic features and the intricate film language, all of which are related to film studies. Some scholars 
also tried to assimilate the film with the literary text by deploitating the narrative function of the film-preambles. The essay On the Forms and Narrative Functions of Film Preambles at Present by Chen Linxia is typical in this branch. Ang Lee attaches great importance to the plot and rhythm in his treatment of film preambles, and favors classical narration. This is a very striking feature of Ang Lee's films. However, the discussions are very traditional and there is little touching on its cultural exploration.

In Culture Studies, the embodiment of Occidental and Oriental cultures, Ang Lee's attitudes toward Chinese traditions and his divarication to the theme of homosexuality are popular topics. In Diverse Identities in Interracial Relationships: A Multi-ethnic Interpretation of Mississippi Masala and The Wedding Banquet, Lan Dong build upon theories of multi-ethnicity and inter-ethnicity in his examination of heterogeneity and multiplicity within the body we label "Asian diaspora". This essay helps us to note the prominent muitiethnic and interethnic relations among racial groups, while hasn't pointed out the location of Asian-Americans' culture identities. In The Oriental and Occidental Cultural Aspects in Ang Lee's Films that published in Huawen periodical, Li Chen dwells her discussion on the different cultural concepts on Ang Lee's trilogy: Pushing Hands, The Wedding Banquet and Eat Drink Man Woman and also the director's individual opinion upon the future for Chinese films. Her article helps us to learn much about Occidental/Oriental culture, while has little touch on the problems of identity. Li Hui, in her essay The Cultural Wonders in Ang Lee's Films, carries out a research on the collision between different cultures. The compromise of the conflict signifies that Chinese culture is being marginalized. The author is very pessimistic about Chinese culture, for she doesn't realize the characteristic of hybridity of culture. This Scenery is Good Alone-Random Thoughts about the Film of Homosexuality is an essay hitting upon the topic of homosexuality. Its author, Zhou Qiongrui holds that The Wedding Banquet represents the aesthetic style at the beginning of the new century. This new wave of films of homosexuality was receiving great attention, especially after the release of Ang Lee's another film—Brokeback Mountain. This observation is popular among many critics. However, as Wang Ping records in his article, what Ang Lee himself wants to emphasize in this film is the power of love, which can overcome cultural difference no matter between the same sex or between woman and man (Wang, 2004, p. 87). The essay The Paradox of Transgressing Sexual Identities: Mapping the Micropolitics of Sexual/Subjectivity in Ang Lee's Films written by Che-ming Yang intends to adopt a perspective of multiculturalism by focusing on the films of Ang Lee. To be more specific, the objective of this essay is no more than an attempt to (re)examine some contemporary means of representation (e.g. pop music, films, novels, TV programs) as manifested in Ang Lee's films of gender in the hope of exploring the process and problematic of cultural formations in the era of globalization characterized by multiculturalism. Che-ming Yang argues that Lee's representation of sexual identity corresponds to Butler's major argument about the contingency and transgressivity of sexual desire/identities. His essay mainly talks about the homosexual problem in Ang Lee's films, while other problems met by the diasporas are excluded. All of the above essays provide different ways for us to understand Ang Lee's films, but have not probed deeply enough under the general "culture" to deal with the sensitive political topic of "culture-identity".

Based on the research findings mentioned above, this paper intends to move beyond the surface structure of the Sino-American cultural clash, furthers into the identity politics, and examine the cultural identity problems in the modem migratory era. The critical analysis of Ang Lee's The Wedding Banquet will reveal how immigrants' identities are constructed in the Sino-American cultural context, and that the cultural identity is not static but in the dynamic process of becoming. Encountering social hurdles and crossing cultural boundaries, the immigrants will be able to cultivate new identities. The focus of this paper will be on presenting the process of the reconstruction of the immigrants' identities in The Wedding Banquet. In the study of the film, the following research questions are to be closely examined:

1) In what way do the Chinese way of wedding banquet and the case of homosexuality represent the cultural confrontation and identity crisis?

2) What factors are functioning in the process of the reconstruction of immigrants' culture identity?

3) What is the location for the immigrant's identity in an ever-increasing trend of globalization?

\section{Body}

\subsection{Identity-Seeking}

\subsubsection{Stages of Identity Formation}

Identity formation is the process of the development of the distinct personality of an individual regarded as a persisting entity (known as personal continuity) in a particular stage of life in which individual characteristics are possessed by which a person is recognized or known (Scholte, 1996, p. 39). This process defines an individual to 
others and themselves. The construction of identity, personal and collective, is a pervasive and crucial aspect of social life. That is to say, the need for recognition - to define oneself (or who one wants to become) and to have that identity acknowledged by others - is a first-order preoccupation in social relations. There are modern questions of culture that are transferred into questions of identity. "Cultural identity is the (feeling of) identity of a group or culture, or of an individual as far as she/he is influenced by her/his belonging to a group or culture, and cultural identity remarks upon: place, gender, race, history, nationality, sexual orientation, religious beliefs and ethnicity" (Barker, 2000, pp. 231-2). The pursuit of identity ranks alongside quests for subsistence, power, communication and knowledge. The process of shaping identity is, among other things, at the core of human existence (Scholte, 1996, pp. 39-40). Based on this recognition, it is not difficult to understand why identity-seeking has always been a motif in cross-cultural films. Chinese Americans have been struggling with psychological and social dilemma of the identity crises ever since their immigration to America, so identity-seeking naturally becomes one of the most important themes in Chinese American films.

As Barbara Warren (1973) points out, "the movement from childhood into maturity is a movement into consciousness of ourselves as subjects - a consciousness that lifts us from a stage of development in which we are cared for by other people to one in which we must take care of ourselves" (p. 2). Though everyone is tempted to stay in the child's world forever if the outside world reality permitted, a person has to go through three stages of identity formation in earning the right to be called fully human, an essential individual. If a culture serves as a homebase for identity-seeking, the three stages can be termed as "home-keeping", "home-leaving" and "home-accepting".

The first stage is that of the child when one is naively unaware of cultural conventions and surroundings. "Home-keeping", or exclusion from the outside world keeps one in a state without any doubt or suspicion. An identity is shaped by those who are close to the child, and forged from the perspective of other people such as family members, and the adults and other individual around the child.

This initial upbringing, limited as it is, may not stay on a par with entanglement in the variety of social relationships. That is to say, even during the first stage, the "Other" (culture, rationality, logic), in a sense, operates behind the scenes. It is this awareness of the tension between the "Self" (nature, naivety, imagination) and this "Other" that leads to "home-leaving" at the second stage. The pressure of "growing-up" drives one forward into the real world, and begins to produce effects at the very beginning of this period. Thus, a critical result appears: disappointment at what one has learned and grasped eagerness for new things and new knowledge. In this period, how to survive in the world becomes the most serious problem, and "making a living" becomes the most important thing in one's life. Hardships require abilities, and naivety is bound to be replaced by miseries or agonies. Therefore, gradually, people struggle to gain their identity.

The problems in this identity-recognition process cannot be solved until the third stage - "home-accepting", when one feds at home with oneself. In this stage, one's "identity-seeking" process becomes quite natural for it conforms to human life in the respect of the latter's temporal being in the world, such as one may fulfill one's target of career, finds one's basis to interpret the world, etc. The identity is there within the process of its seeking, rather than in the structure of the given culture defining and restricting it.

Obviously, this process of identity-seeking would be much more complicated in multicultural circumstances, comparing within a given culture. An ethnic identity is the identification with a certain ethnicity, usually on the basis of a presumed common genealogy or ancestry. Recognition by others as a distinct ethnic group is often a contributing factor to developing this bond of identification. It could be understandable that Chinese immigrants often find themselves in an identity dilemma when they are in America, especially where are different kinds of racism, which encourage the breakdown of their traditional Chinese values, and they have to struggle with a new culture. They are often confronted with such questions as: What is their place in America? What are their responsibilities? What should they teach their children? How many of the Chinese ways are to be trained? In what ways are they to keep their ethnic identity but still become Americans? So, how to define oneself and how to locate oneself becomes a common puzzle for the immigrants.

\subsubsection{Identity Dilemma of Ang Lee}

Ang Lee was born in Taiwan, while studied film and started his directorial career in the United States. It is the personal daily life experience of being "Chinese" in New York City that drives Ang Lee to invoke Chineseness in his films to define his identity. According to William Safran (1994), the"ideal type"definitions of diasporas are those who form "expatriate minority communities" and they have the following characteristics: 1. They are dispersed from an original"center"to at least two peripheral places; 2. They maintain a"memory,vision,or myth about their original homeland"; 3 . They"believe they are not-and perhaps cannot be-fully accepted by their host 
country"; 4. They see the ancestral home as a place of eventual return; 5 . They are committed to the maintenance or restoration of the homeland;and 6 . The group's consciousness and solidarity are "importantly defined" by this continuing relationship with the homeland (Clifford, pp. 304-5).

Ang Lee's real-life experiences exemplified what Safran described. Although he was physically displaced from Taiwan to the U.S., as a second-generation mainlander growing up in the social background of identifying with the China Proper and de-Taiwanese cultural policies enforced by the ruling Nationalist Party (Kuomingtung) back then, Ang Lee symbolically and culturally went through twice displacements from his imaginary homeland - China. Especially with the rise of ethno-racial issues in the 1990s, identity problems become more troubling for the immigrants in America. People come to realize the shallowness of American identity as it clouded diversity of culture. To the Chinese Americans, should they be called Chinese, American, or Chinese American? These questions are quite thorny as they try to make a proper evaluation of their identity and belonging. Being in a totally new place, the immigrants have to learn the new language and culture. They have to cope not only with the sense of nostalgia but often also with the hostility of a unfriendly population. For many ethnic Chinese, who have been away from their ancestral homeland, find themselves in a dilemma: they are essentialized by the Anglo whites sometimes as the "Yellow Peril," sometimes as the "Model Minority," and their life becomes therefore a constant struggle to find and maintain their proper self and sense of belonging. Even on the settler status was taken on the board, clear boundaries are drawn between themselves and their white neighbors. While some boundary walls are breaking down, others are being made even stronger to keep out the migrant, the refugee and the exile. They are included and excluded in many ways. "Language, nostalgia, loss, search for identity" are the problems the emigrants have to face (Hall, 1996, p. 5). Speaking a new language, the emigrants will find that the signifier has become severed from the signified. The words they speak don't stand for things in the same unquestioned way they did in their native tone. Gradually, their mother language becomes a dead language. After a process of falling into the new life, the emigrants would gradually begin to feel at home in "The New World". They share with their American locals an acute sense of dislocation and the equally acute challenge of having to invent a place and an identity for themselves without the traditional supports. However, they still cannot avoid the feelings of anomie, loneliness and emotional repression. Some people don't feel at home where they are; they are unhappy and they look back. They are still assailed by the problems of identity. They are remade in the new frames of culture. "Their identity is to do not with being but with becoming" (Hall, 1996, p. 6). For Ang Lee, he himself once describes his own experience of being diaspora in New York as follows:

"To me, I am a mixture of many things and a confusion of many things... I am not a native Taiwanese, so we're alien in Taiwan today, with the native Taiwanese pushing for independence. But when we go back to China, we're Taiwanese. Then, I live in the States; I am a sort of foreigner everywhere. It's hard to find a real identity." (Berry, 1993, p. 54)

\subsubsection{Identity-Seeking as Seen in the Film}

Ang Lee's The Wedding Banquet (1993) is a film that transcends, on a metaphorical level, to a story represents the issue of the Asian diaspora's identity as a mixture. Gina Marchetti (2000) incisively points out that this film "deals less with the development of an Asian American identity among Chinese immigrants than with the creation of a transnational sense of Chinese identity" (p. 54). In this film, Ang Lee tries to explore various Chinese identities-young/elder, man/woman, heterosexual/homosexual, all combined to form a feast of human interactions that allow us to reflect on the process of the identity-reconstruction.

From the very beginning of the film, the audience learn that Wei-Tung is a successful real estate man and an American citizen. He leads a comparatively wealthy life, with a man loves him. He has assimilated to American culture successfully. The only thing that frustrates him is the secret (gay relationship with Simon) that he keeps from his parents. No matter how much he loves and respects his parents, and how carefully he keeps all of their tokens and gifts from Taiwan, Wei-Tung dares not to tell them the truth of his real sexual identity. Here is a dialogue reveals Wei-Tung's dilemma at the beginning of the film:

Simon: Why don't you just tell them?

Wei-Tung: Shit.

Simon: No, really, Wei. Someday, I am just going to call your father and tell him myself.

Wei-Tung: I told mine.

Simon: Look at yourself. Your parents send you a form in the mail and you practically pee your pants. You are an adult. As a matter of fact, you're practically middle-aged. 
However, we know that Wei-Tung does not confess his sexual orientation to his parents until the family conflicts break out. As an obedient Chinese son, he cannot tell it out frankly for the Oriental identity is characterized by having a family and strongly believing in filial piety. Wei-Tung is afraid of his parents' reaction and the familial ramifications that his "coming out" would bring.

"So heavy!" Wei-Tung exclaims early in the film, as we watch him walk, weighted down by the "heavy baggage" of his parents' gifts. In this scene, we can clearly sense the heavy burden on his psyche. He suffers fragmentation of identity and role confusion (how can he be the good son while also being at peace with being gay?). Such a conflict is inevitable when a person is unable to integrate their conflicting roles. As the only child, Wei-Tung's family expects much from him, and expects it rigidly. In the dialogue talking about Wei-Tung's father's illness between Wei-Tung and Sister Mao (the girl from Singled Club in Taiwan to have a date with Wei-Tung, which is settled by Wei-Tung's mother), the expectation from Wei-Tung's family can be felt clearly:

Sister Mao: Your mom told me that when they took him in the ambulance, there was a huge traffic jam. He was in pain, really suffering. She thought he was going to die, but he hung on for one last wish.

Wei-Tung: What wish?

Sister Mao: To hold his grandchild.

Wei-Tung: What's this?

Wei-Wei: My depression special.

Wei-Tung: You're really that poor?

Wei-Wei: Just depressed. Immigration showed up at work yesterday. Luckily I got there late.

Wei-Tung: As usual.

Wei-Wei: Yes. They got Emily. If they get me, I'll be meeting Emily in Shanghai. Emily was my best friend.

Now I've lost my job and my friend.

As a Chinese American woman, it is more difficult for Wei-Wei to consolidate a new gender identity in America, because her gender identity development is further complicated by the dual forces of sexism and racism both in the culture of origin and in the majority culture. It is widely recognized that Chinese American women suffer double oppression. They are the victims of both American hegemonic ideology, which devalues them because of their race, and patriarchal ideology (Note 1), which devalues them because of their gender. Such devaluation poses serious challenges for Chinese American women in terms of achieving an independent personal and group identity. So for Wei-Wei, as she herself also realized that, if she wants to stay in America,she has to marry an American citizen:

Wei-Tung: You've been having so many troubles, and all I do is pressure you for rent. Here. I brought you an air conditioner.

Wei-Wei: But the electricity costs? Out of work again. I'm such a fool. Always hoping you'll like me.

Simon: Anyway, Wei and I would like to invite you out to dinner.

Wei-Wei: It will be my farewell dinner.

Wei-Tung: Your what?

Wei-Wei: Really. I can't last any longer. No money, no job, no green card. No stupid American will marry me.

So, it is no wonder why Simon suggests a marriage of convenience between Wei-Tung and Wei-wei. In this way not only can Wei-Tung defer the suspicions of his parents and take a big tax break, but also for Wei-wei, she can stay in America legally. However, such things are never so simple and ideal. Wei-Tung and Wei-wei will continue to face the cultural clash and identity clash if they remain so innocent and idealistic in their understandings of the multicultural society and the Americanness identification. When the issues of the Chinese way of wedding feast and the case of homosexuality come into the foreground, their perfect solution to the problems failed.

\subsection{The Location of the Immigrants' Cultural Identity}

\subsubsection{Fragmentation and Transformation of Chinese Immigrants' Identity}

Identity is really a puzzle to many diasporic Chinese immigrants, because it involves questions of "Who am I?", "Where do I belong?" and "Where shall I go?", which are fundamental to people's survival. The meaning of identity in modem times, as Christopher Lasch (1987) points out that: "refers both to persons and things. Both 
have lost their solidity, their definiteness and continuity." (pp. 23-29). These identity problems faced by ethnic minorities are attributed to a great extent to the rise of colonialism, as Frantz Fanon (1967) says, "because it is a systematic negotiation of the other person and a furious determination to deny the other person all attributes of humanity, colonialism forces the people it dominates to ask themselves the question constantly: "In reality, who am 1?" (p. 87) Therefore, it is quite understandable that immigrants often feel homeless and lose sense of belonging in the host culture.

In the process of identity reconstruction, as Turaine (1988) said, "the individual or collective appeal to identity is thus the obverse of social life, whereas the latter is a network of relations, the focus of identity is all at once that of individual, communities and states" (p. 75). That is to say, people's identity is affected by different social and cultural factors, which function in the process and compete with each other for the control of the individual subjectivity. The individual then has to be "constantly subjected to a range of possible meanings, and is therefore an unstable site of constructions and reconstructions which often overlap" (Easthope, 1996, pp. 68-9).

At the beginning of the film, we see Wei-Tung as a somewhat selfish young man who has attempted to assimilate American culture. But at the end, we can clearly notice the change of Wei-Tung into a more mature adult, ready to shoulder real responsibility in a committed homosexual relationship. We see a man who has made peace with his identity as a gay man from a traditional Chinese culture and as a caring and filial son who accepts his duty to the family. In the end, Wei-Tung is fully aware the cultural shaping of his hybridity and the fragmented building of his consciousness, which is the very source of his confusion about cultural identity.

According to the anthropologist Gordon Matthew (2000), the culture shaping of the self within any culture is basically thought at three different levels of consciousness: the deep shaping that takes place beyond the self's control and beyond all but indirect comprehension; the middle-level shaping that exists beyond the self's full control but within its comprehension, and the shallow shaping that all comes into being with what the self sees as full control and comprehension (pp. 12-15). This model of culture shaping is not only helpful in the analysis of the personal identity, but also illuminating to the explanation of the hybridity construction in American cultural settings. On these grounds, Wei-Tung's identity hybridity and confusion could be better understood.

First, there is, deep at bottom, what Matthew (2000) regards as the "taken-for-granted level" of consciousness shaping, which means the shaping by a particular language and set of social practices that condition us as to how we comprehend self and world (ibid p. 12). Generally speaking, this level of consciousness is formed and constructed unconsciously in the process of socialization and in due time evolves for the most part below the level of consciousness (ibid p. 13). As in The Wedding Banquet, before immigrating to American, Wei-Tung has been nurtured by the Chinese culture, thus the value of family has been rooted as a part of his deep memory in subconscious. Even after successfully embodying the America's commonly prescribed values of competition, success, achievement, and perfection, his Chinese cultural shaping at this level will never disappear, as it withdraws from the foreground to the background. To some extent, it is hard to escape from the cultural shaping at this level, because such a period of socialization and acculturation applies to all.

The middle level of the cultural shaping is at what Matthew (2000) call the "shikata ga nai level",which means "there is nothing I can do about" or "that is life". This level is expected by the self not as "underlying but as extrinsic to the self" (ibid p. 13). At this level, the construction of "self" is bound by "the power of discourse". Usually, the individual subject is aware, partially or fully, of the hegemonic essence of the cultural discourse, but the real problem is that there is no chance to act against it so long as he still wants to be "in" the culture. We can see this more vividly in Wei-wei. As a Chinese immigrant, Wei-wei is an independent woman living by herself trying to make ends meet anyway she can at the beginning. She is a painter but has part time jobs such as being a waitress. But finally, she becomes domesticated and lives as a traditional Chinese woman: she is married with a child, wears long conservative dresses rather than the bizarre ones she wore before, and her hair is nice combed. Only through this transformation, she can get the "green card" and safely lives in America and then come to realize her American dream.

The third and also the most shallow and most fully conscious level of the cultural shaping involves the formation of "the cultural supermarket" (ibid, p. 14). It is the level at which any individual can feel that they are able to freely pick and choose the way they want to live in. Globalization and multiculturalism bring the cultural supermarket into being, in which all cultures confront and communicate and individuals are given the freedom of choice and identification. At this level of "free" identifications, Wei-Tung tries to make a balance between American and Chinese culture - the conflicts involved in the film The Wedding Banquet seem all solved: Wei-Tung's parents accept the truth of their son's sexual orientation, Wei-wei promises to keep the up-coming baby, while Simon also agrees to stay with Wei-Tung as "the other father of the baby". Wei-Tung arrives at the "symbolic identification" 
where he can identify himself with his will. In a sense, it is a level of freedom and liberation, but somehow it is still a freedom under the manipulation and maneuver of the dominant culture, and the remembrance of the native culture that will always linger and haunt. One's recognition of identity is very situational. Just like Wei-Tung, his suffering of fragmentation at first is at least partly due to his ignorance of himself, especially of his situation of hybridity. In one situation he can feel very American, at another time Chinese - or hold both identities at the same time. But this recognition of the multiplicity and situationality of social identities does not mean that people can freely choose any identity they want or to attach any meaning they want to any particular identity. History and current power relations create and shape the opportunities people face in their day-to-day lives, giving some people "ethnic options" and others "racial labels." (Waters, 1999, p. 47)

So, fragmented between the home and host cultures, the reconstruction of Wei-Tung's consciousness can never be complete and unified and his cultural identity can only be an unstable state of confrontation and communication. In metropolitan cultures like America, it is impossible that the native or the adopted culture can be presented in "pure" sense. We should get to acknowledge the characteristic of "hybridity" of culture.

\subsubsection{Hybridity: Transcendence of Identity as a Way Out}

Different from the traditional logo-centrism in the Western culture to subvert the traditional culture view of binary opposition, what is suitable to the present situation is that hybridity (Note 2) of culture. The cultural hybridization, according to Pieterse, "distinguishes cultural response, which range from assimilation, through forms of separation, to hybrids that destabilize and blur cultural boundaries. This involves the opening up of "imagined communities" (Barker, 2000, p. 256). In the film, two cultural traditions are juxtaposed in time and space. Hybridization only occurs out of recognition of difference and then would produce something new. "All cultures are zones of shifting boundaries and hybridization" (Bhabha, 1996, p. 258). Semantically hybridization refers to the mixture or blending of two different or even contrastive elements, while pragmatically it refers to crossbreeding and suggests inferiority. But its meaning has undergone dramatic changes in the past few decades. Originally it was used in the field of botanical or biological studies, referring to the selective breeding of plants to produce new varieties with specific qualities of the improved performance, and later it was considered as a "stigma" in the colonial discourse concerning racial purity and the horror of "miscegenation" (Young 10). Now this word is usually thought as "crossing the races" and accepted by many scholars, even by those who are unwilling to realize the hybridization of cultural identities.

In the film, after a series of tricks played by the young generation, all of them get frustrated and come to confront their true identities. In Wei-Tung's self-confessed conversation with his mother, he takes a critical step toward wholeness. For the first time, he openly embraces all aspects of his being. Having Confessed his deepest secret, he is freer to channel his energies to handle his other identity crisis. Wei-Tung's way of adaptation to western world is quite conventional, fully accepting America's established values of competition, success, achievement, and perfection. Successfully embodying these cultural values allows him to experience the rewards of social acceptance, accomplishment, power, and personal satisfaction. As an Eastern immigrant successfully assimilated into the Western cultures, Wei-Tung demonstrates an exceptionally fluid identity with an ability to navigate a duality of worlds --- that of homosexual and heterosexual; Asian and American. By the marriage to Wei-wei, Wei-Tung got a child unintentionally. Therefore, with the "new family", Wei-Tung must mediate between having Simon as his true partner and accepting Wei-wei and the child as his nuclear family. Having tried to make a balance between Western and Eastern cultures, Wei-Tung creates a new concept of family allowing him to fulfill his familial responsibility of carrying on the family line. Wei-Tung's fake marriage with Wei-wei provided a mechanism to re-assimilate him into the mainstream Chinese culture. He has gained some self-awareness, has deepened his intimacy with the people he values, and has relieved his burden of concealment. He has begun to integrate his identity and realized the conception of "hybridity" of culture.

Homi Bhabha (1996) once describes the basic nature of cultural hybridization as this: "the transformational value of change lies in the rearticulation or translation, of elements that are neither the one, nor the other, but something else besides, which contests the terms and territories of both" (p. 28). Evidently, the most characteristic feature of the cultural hybridity is the ambiguity and the indeterminacy. But how to understand the "ambiguity" will solicit the contrastive attitudes toward hybridity and result in very different cultural prospects. To understand it as a static and ossified term and take the ambiguity as a loss of unity and identity will incur the so-called phenomenon of hybridity-phobia.

In The Wedding Banquet, Mr. Gao is wise enough to understand the problem faced by his son and accepts his true identity by the end. The final take of the helpless father-raising his arms in slow motion to be frisked by the airport security- suggests a submission to life by an aged retiree as a possible victory for gaining an heir - a grandson - to 
the Gaos. After all, shortly before the departure, the father, a typical Chinese male who makes little physical contact, holds tightly Simon's hand rather than Wei-wei's to bid farewell, fully acknowledging Simon as a member of the family. The father seems to give his blessing to the formation of a happy yet non-conventional family. His acceptance of an alternative marriage may drive from a rather conservative reason, though, namely, the prospect of carrying on the family name through the homosexual son. That is to say, the ethnic tour into the gay interracial lifestyle is normalized and mainstreamed by a traditional premise. This transformation did not appear to be painful at all. Though even Mrs. Gao still thought that" maybe it (homosexuality) is only temporary. He may get over it. Maybe a woman hurt him and he developed a psychological problem". But Wei-wei confirms her that it's not like what Mrs. Gao thought, she had better accept the truth. Mrs. Gao acknowledges this by saying: "I know that". Through this, Ang Lee wants to convey the idea that the problem of homosexuality can be solved through negotiation. As exemplified by Mr. Gao, it is not that difficult to accept homosexuality even for a very traditional Chinese citizen. Lee creates a win-win situation in which homosexuality is accepted while familial duties (to marry and have children) are also fulfilled:

Wei-wei: I will find a way. A tough man takes responsibility for his actions.

Wei-Tung: Wei Wei wants to know if you will be one of the fathers of her child.

Simon: Sure.

Wei-Tung: Then you'll stay?

Wei-wei: You must, for the sake of the child. Now that I'm keeping the baby, we'd better go tell Pa, he's going to be a grandfather. He'll be so happy.

Ang Lee develops this plot and exploits it in order to express his views on homosexuality and its compatibility with the Chinese traditions. Only after the traditional understanding of the hybrid ambiguity is transcended and a positive and dialectic appreciation achieved can the problem of culture and identity be properly addressed.

Likewise, ambiguity or hybridity can be political in its inborn resistance to any forms of cultural domination and discrimination. Homi Bhabha points out,

"Resistence is not necessarily an oppositional act of political intention, nor is it the simple negation or the exclusion of the 'content' of another culture, as difference once perceived...[but] the effect of an ambivalence produced within the rules of recognition of dominating discourses as they articulate the signs of culture difference" (Bhabha 153)."

In his opinion, cultural resistance does not necessarily mean the violent confrontation or serious opposition of one culture against another; it means the deployment of ambivalence or ambiguity within the dominant cultural framework through inevitable deformation and displacement. And in this special way hybridity "unsettles the mimetic or narcissistic demands of colonial power but re-implicates its identification in strategies of subversion than turn the gaze of the discriminated back upon the eye of power" (ibid 173). In this sense, though ambiguity or ambivalence is the main strategy of cultural hybridity in subversion, ambiguity in identity does not necessarily mean the ambiguity of consciousness. Alternatively, hybridity does not simply mean the overlapping of two kinds of cultural consciousness, but the rebirth of an entirely new cultural self.

In the end of the film, it seems that everyone is happy, and they seem to have a greater understanding and respect for one another's choices. The fake marriage between Wei-Tung and Wei-wei creates many conflicts, and forces each character to rethink what his/her identity is. Ang Lee proposes a solution for this problem of homosexuality in this film. Finally, Wei-Tung screws up his courage and confesses that he is gay. Even though Mrs. Gao is not willing to accept the truth at the beginning, she too is forced to embrace her son for who he is. In the end, we see all the different people (identities) make peace with one another; the greatest indicator of this is when Mr.Gao accepts Simon as his son's partner. It may well be argued that this is the result of Wei-wei's pregnancy, the coming of a child is a promising sign of new identity shaped by the combination of very different identities. This also signifies that cultural purity has become only a beautiful dream in today's era of globalization and multiculturalism, and in its place is hybridization.

\section{Conclusion}

In the previous discussion, we have dwelt on how Chinese immigrants tried to establish new cultural identity of their own by negotiating the contradictions between the Eastern and Western worlds. Given the racialized and politicized themes in the film The Wedding Banquet as well as the director's personal ethnic background as an Asian director, great attention have been paid on the film The Wedding Banquet. With the above discussion, the 
process in which Asian Diasporas come to realize and negotiate for their individual identities of diversity and complexity is highlighted. We can sense that diaspora culture is a continuous process, and the relationship between the diaspora culture and the host culture is, according to Homi Bhabha (1996), a "negotiation" (p. 23). The diasporic culture adapts itself optionally to the host culture, merging and developing into a new culture which is closely linked to, however meanwhile, different from,the host culture and home culture. This cross-culture process is often described as "hybrid", which Homi Bhabha (1996) regards as the product of cultural translation (p. 34). In this process of cultural translation, the diasporic identity is consistently renewing and transforming due to the differences.As Stuart Hall (1996) asserts that cultural identity is a matter of "becoming" as well as "being", being to the future as well as to the past (p. 38). Contemporary cultural pluralism and globalization has offered an opportunity for greater density of cross-cultural interchange: the reduction of the physical boundedness of time and space, and the breaking down of the natural connections between identity and place, identity and tradition, particularly on the immigrants' part. Under such circumstances, the focus of identity construction should be relocated from differentiation to melting point. The construction of one's identity should no longer depend on the erasure of what one is not. The "Self" is to be partly discovered in those who were previously described as the other. Not only can hybridity be a subverting strategy to resist the hegemonic identification and discrimination from the dominant culture, but also can be an effective way to release the immigrants from the suffering of cultural dislocation and identity fragmentation. Through analyzing the film critically, I am tempted to point out that hybridity is a noteworthy keyword in identity politics: it is not only an ideal state of cultural identity in theory, but also the ultimate direction of the movement of both cultures and identities in real life.

\section{Notes}

Note 1. Chris Weedon defines "patriarchal" in Feminist Practice and Poststructuralist Theory as "power relations in which women's interest are subordinated to interest of men" (1997, pp. 1-2).

Note 2. Originally, hybridity is a technical term in the Botanical Studies and then extended in its implication. Robert Young appropriates the term to the ethnographical studies and especially in the studies of black-white hybridity in his great critical work Colonial Desire: Hybridity in Theory, Culture and Race, London: Routledge, 1995. Then Stuart Hall and Bhabha introduce the term to the field of cultural studies and initiate the study of hybridity in culture field. In the cultural studies, hybridity means not only the mixture or blending of two collective cultural identities on the part of cultural subjects. For more information, please refer to their books in this field, such as, Bhabha's Location of Culture, Hall's Cultural Identity and Diaspora, etc.

\section{Conflict of interests}

The authors declare that there is no conflict of interests regarding the publication of this paper.

\section{References}

Althusser, L. (2000). Ideology Interpellates Individuals as Subjects. In P. D. Gay \& J. Evans (Eds.), Identity: A Reader. London: SAGE.

Barker, C. (2000). Central Problems in Cultural Studies. Culture Studies: Theory and Practice. London: SAGE.

Berry, C. (1993). Taiwanese melodrama returns with a twist in The Wedding Banquet. Cinemaya, 21(Fall), 52-54.

Bhabha, K. H. (2004). Within Third Space. In H. Bhabha (Ed.), The Location of Culture. London: Routledge.

Butler, J. (2000). Critically Queer. In P. D. Gay \& J. Evans (Eds.), Identity: A Reader. London: SAGE.

Clifford, J. (1994). Diaspora. Cultural Anthropology, 9, 302-338.

Derrida, J. (2000). Difference. In P. D. Gay \& J. Evans (Eds.), Identity: A Reader. London: SAGE.

Dikotter, F. (1992). The Discourse of Race in Modern China. London: C. Hurst \& Co. Ltd..

Easthope, A., \& Kate, M. (1996). A Critical and Cultural Theory Reader. Buckingham: Open University Press.

Fanon, F. (1967). Black Skin. White Masks. Charles Lamm Markmann (trans.). London: Pluto.

Foucault, M. (2010). The Archaeology of Knowledge and the Discourse on Language. New York: Vintage Books.

Fred, E. J. (1995). Intercultural Communication: An Introduction (p. 373). Thousand Oaks. CA: Sage Publications.

Galbraith, L. (1993). Cultural Clash. (Interview of Ang Lee). Outrage, 30-33.

Grossberg, L. (2005). History, Politics and postmodernism: Stuart Hall and Culture Studies. In D. Morley \& C. K. Hsing (Eds.), Critical Dialogue in Cultural Studies. New York:Routledge. 
Hall, S. (1996). New Ethnicities. In D. Morley \& C. K. Hsing (Eds.), Stuart Hall: Critical Dialogue in Cultural Studies. London \& New York: Routledge.

Hall, S. (2000). Cultural Identity and Diaspora. In C. Barker (Ed.), Cultural Studies: Theory and Practice. London: SAGE.

Hall, S., \& Du Gay, P. (Eds.). (1996).Culture's In-Between. In S. Hall \& P. D. Gay (Eds.), Questions: Cultural Identity. London: SAGE.

Hardesty, M. (2001). Feature Nominees. PGA Magazine, 20-24.

Hooks, B. (1996). Reel to Reel: Races, Sex and class at the Movies. New York: Routledge.

JanMohamed, A. R. (1986). The Economy of Manichean Allegory: The Function of Racial Difference in Colonist Literature, London. Critical Inquiry, 12, 58-71.

Kwok, K. W. (1996). Historical Discontinuity and Cultural Dislocation: The (Non-) Problem of Social Memory in Singapore, paper presented at the conference on Trauma and Memory. Durham: University of New Hampshire.

Laird, J. (1993). Lesbian and gay families.Ed.F.Walsh. Normal family processes. New York: The Guilford Press, 282-328.

Lasch, C. (1987). What's Wrong with the Right? Tikkun, 1, 23-29. Retrieved from http://thor.clark.edu/sengland/previous\%20features/a_dialogue_with_Christopher_Lasch

Marchetti, G. (2000). In D. Y. Hamamoto \& S. Liu (Eds.), The Wedding Banquet:Global Chinese Cinema and the Asian American Experience. Countervisions: Asian American Film Criticism. Philadelphia: Temple University Press.

Mathews, G. (2000). Global Cultural/Individual Identity: Searching for Home in the Cultural Market. London and New York: Routledge.

Portes, A., \& Macleod, D. (1996). What Shall I Call Myself? Hispanic Identity Formation in the Second Generation. Ethnic and Racial Studies, 19, 527.

Rutherford, J. (1990). A Place Called Home: Identity and the Culture Politics of Difference. In J. Rutherford (Ed.), Identity: Community, Culture, Difference. London: Lawrence \& Wishart, 12-38.

Safran, W. (1991). Diasporas in Modem Societies: Myths of Homeland and Return. New York: Cambridge University Press.

Said, E. (1983). After the Last Sky. New York: Pantheon.

Said, E. (1993).Culture and Imperialism. London: Chatto \& Windus.

Sarup, M. (1996). In R. Tasneem (Ed.), Identity, Culture and the Postmodern World. Edinburgh: Edinburgh University Press.

Scholte, J. A. (1996). Globalization and Collective Identities. In J. Krause \& N. Renwick (Eds.), Identities in International Relations. Houndmills, Hampshire: Macmillian Press.

Selden, R. (1985). A Reader's Guide to Contemporary Literary Theory. London: Prentice Hall.

Turaine, A. (1988). The Return of the Actor. Minneapolis: University of Minnesota Press.

Wallerstein, R. S., \& Goldberger, L. (Eds.) (1998). Ideas and Identities: The Life and Work of Erik Erikson. Madison, CT: International Universities Press.

Wang, N. (2004). Globalization Theories and Contemporary Chinese Culture Criticism. Literature and Art Reascarch, 1, 78-81.

Warren, B. (1973). The Feminine Image in Literature. Rochelle Park, New Jersey: Hayden Book Company, Inc..

Waters, C. M. (1999). Black Identities: West Indian Immigrant Dreams and American Realities. Cambridge, Massachusetts \& London: Harvard University Press.

Webster, D. (1994). Pessimism, Optimism, Pleasure: The Future of Culture Studies. In J. Storey (Ed.), Culture Theory and Popular Culture. London: Prentice Hall.

Williams, R. (1994). The Analysis of Culture. In J. Storey (Ed.), Culture Theory and Popular Culture. London: Prentice Hall.

Williams, S. (1991). Diasporas in Modem Societies: Myths of Homeland and Return. Diaspora, l(1), 91-93. 
Wu, C. T. (Ed.) (1972). Chink! A Documentary History of Anti-Chinese Prejudice in America. New York: World Publishing Co..

Young, R. (1995). Colonial Desire: Hybridity in Theory, Culture and Race. New York: Routledge.

Zastrow, C., \& Kirst-Ashman, K. (1994). Understanding Human Behavior and the Social Environment. Chicago: Nelson-Hall.

\section{Copyrights}

Copyright for this article is retained by the author(s), with first publication rights granted to the journal.

This is an open-access article distributed under the terms and conditions of the Creative Commons Attribution license (http://creativecommons.org/licenses/by/4.0/). 